\title{
Parallels and Analogies in the Interwar Architecture in Latvia and Czechoslovakia
}

\author{
Renāte Čaupale, Riga Technical University, Latvia University of Agriculture
}

\begin{abstract}
The interconnections of the interactions between the art and architecture of the Latvian and Czechoslovakian nations are relatively fragmented. However, there is one large European cultural space in which both parallels and analogies can be found, as required by the communicative role of art and architecture. In the 1920s and 1930s, a European architecture that was founded on modern features could be found in the architecture of the new Latvian state. Art Deco aesthetics was one of the operative events of the interwar period. Its expression changed along with the changes occurring during this time period, retaining the decorativeness principles of Art Deco. Art Deco aesthetics encompass several distinct but related design trends, including the following: interpretation of elements of folklore - Ansis Cīrulis in Latvia and Pavel Janák in Czechoslovakia authored masterfully designed interior examples. Regardless of their creative potential after the First Wold War, artists and architects in many new states were drawn into the stream of contemporary trends - the folkloristic style, which became one of the decisive sources of inspiration for demonstrating national self-determination, which, in turn, is typical of all cultures and civilisations and can sometimes be international. An analogous interpretation of folklore brings these processes together, which allows them to be identified as folkloristic Art Deco trends. There are moments when folkloristic Art Deco as a component of Modernism art and architecture of the 1920-30s organically foreshadows the aesthetics of pre-postmodernism; modernization of the classic form, which has been highlighted directly in the period of the leader cult common in new states. The wish to represent people's self-determination in architecture and the circumstances of this time shaped the monumentality of the masterpieces designed by Jože Plečnik and Eižens Laube in Prague and Jürmala, respectively, and, at the same time, also their distinct consideration for national heritage. Naturally, a cultural basis that is identical for many European countries can be identified in Latvia and Czechoslovakia, rather than art elements of incidental nature that have randomly entered the country. For this reason, the aim of the present paper is to show the ideological context of Latvian and Czechoslovakian architecture.
\end{abstract}

Keywords: architectural history, the 1920s and 1930s, Art Deco, folkloristic art

\section{Introduction}

The interrelationships in art and architecture between the Latvian and Czechoslovakian nations are relatively fragmented. However, due to their existence within a single large European cultural space, both parallels and analogies can be identified, as defined by the communicative role of art and architecture.

In the 1920s and 30s, specific activities that were characteristic of Europe at that time could be identified within the architecture of the new Latvian state. The aesthetics of Art Deco was one of the most significant architectural and artistic ways of expression during the interwar period, which, although changing as time went by, still retained substantially unchanged principles of Art Deco ornamentation.

The aesthetics of Art Deco comprises a number of different yet mutually interrelated trends. Summarizing the views held by historians regarding US architecture, Eva Weber discusses three significant variants of the Art Deco style: the so-called Zig-zag style (also known as Zig-zag moderne), the conservative version of the 1920 s and 30s (Classical Moderne) and the Streamline
Moderne of the 1930s [30;19]. After the first World War, when news states including Latvia and Czechoslovakia appeared on the European map, efforts at seeking national forms of expression cannot ignored, thus another variant can be singled out, namely, folkloristic Art Deco, that in spite of the seeming different express in any country, "there is nevertheless a true, if hidden, unity, a secret synthesis, in our present civilization" [4].

\section{Latvian and Czech Architecture - Topicality of the Discussion}

Latvian architecture is mostly known in Europe for its outstanding Art Nouveau structures: this was further confirmed by the fact that in 1997, the Art Nouveau buildings in Riga were universally recognized as noteworthy treasures of European cultural heritage and was included in UNESCO's list of World Cultural Heritage. Naturally, Latvia has had historical creative connections with the Scandinavian countries. However, in the field of art, these connections mostly manifested themselves within the framework of national romanticism, with inspiration drawn from Finland. Finnish art and 
architecture influenced the creative work of Latvian architects most at the beginning of the 20th century.

Tender competitions show that there were successful professional relationships with Finland, Sweden and other countries. Architects from Germany, Switzerland, Finland and Poland took part in the tender for the design of the Riga Town Hall in 1897. In 1912, Finnish architect Eliel Saarinen proposed a design for the building of the Riga Craftsmen Society [17]. In 1909, Swedish architect Lars Johan Lehming submitted a design for a hotel in Riga [6]. In the 1930s, art historian Jānis Siliņš, when analysing the architecture exhibition at the City Art Museum that took place at the turn of 1934 and 1935, identified in the architecture both a visible 'Swedish influence' and 'along with it, a couple of American and French influences" [22]. However, this list of intercultural relationships is incomplete, because there are direct or indirect parallels between Latvian architecture and that of other countries as well, and "naturally, a cultural substrate identical to that of other European countries can be found rather than artistic elements of random nature of styles that have been swept in by chance" [23].

If we take a look at the architectural activities at the beginning of the 20th century, historical evidence can be found showing that young Czech architect František Roith, who was a student of Austrian architect Otto Wagner, took part in the tender for the design of the building of the Riga Latvian Theatre [32]. Roith, who had only worked as an independent architect for four years by 1911, proposed a design for a building that was a synthesis of Neoclassicism and early modernism, which was trendy at the time (Fig. 1a, 1b).

Roith implemented his large significant designs as late as after the First World War, in the 1920s and 30 s, when he had already become one of the representatives of the official architecture of Prague. Moreover, although the requirements put forward for the official representation of the time that were based on the classical tradition were met on the outside, Roith's creative work is described as a successful balance between the new monumentalism and the historical monumentality [7]. He was not afraid of introducing stylistic elements of Art Deco into interiors [25; 33.], for example, the geometrical ornaments on the overhead lighting, the walls, ceiling and windows of the stairwell designed according to Art Deco aesthetics, in the stunning hall of Prague City Library (1924-1928; Městská knihovna; Mariánské nám.1). Such light distribution in a hall, which was an innovation in Riga at the time, was implemented in the Large Hall of the University of Latvia in the 1930s (1931-1936),
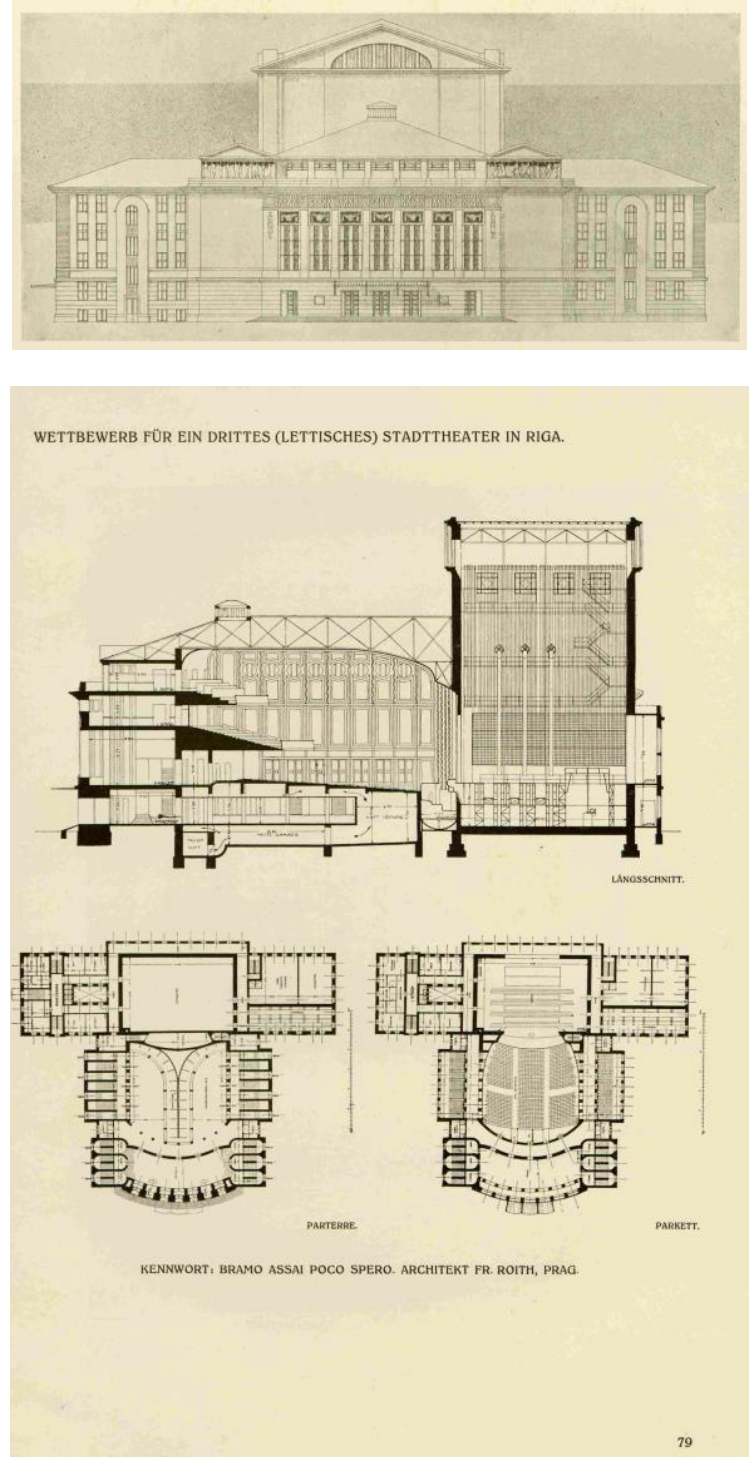

Fig. 1a, 1b. František Roith, propose a design by tender for Riga Latvian Theatre, 1911 [32]

architect Ernests Štālbergs); in 1933, architect Aleksandrs Klinklāvs designed the same thing in his project for the universal hall of the Riga Students' Building, which was never constructed [12].

František Roith designed the façade of the design proposed in 1911 for the Riga Latvian Theatre in accordance with the principles of composition that he would then later implement in his home city Prague in the 1920s: a serenely balanced façade that is divided by pilasters and has relatively large window apertures, which, in the design for the building in Riga, have also been divided by muntins. The large windows are the main accent of the façade, their fragility providing contrast to the bulkiness of the stonework surrounding the windows. One might admit that the 1911 design for Riga foreshadows Roith's future signature style. Ornaments as clearly and undoubtedly classical in style as those envisaged in the design for the 


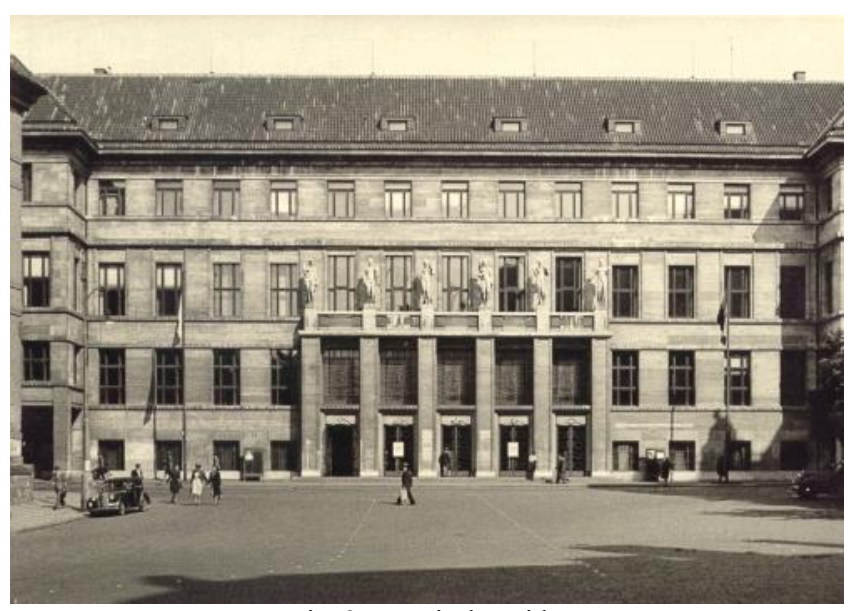

Fig. 2. František Roith,

Prague City Library (1924-1928) in 1947 [39]

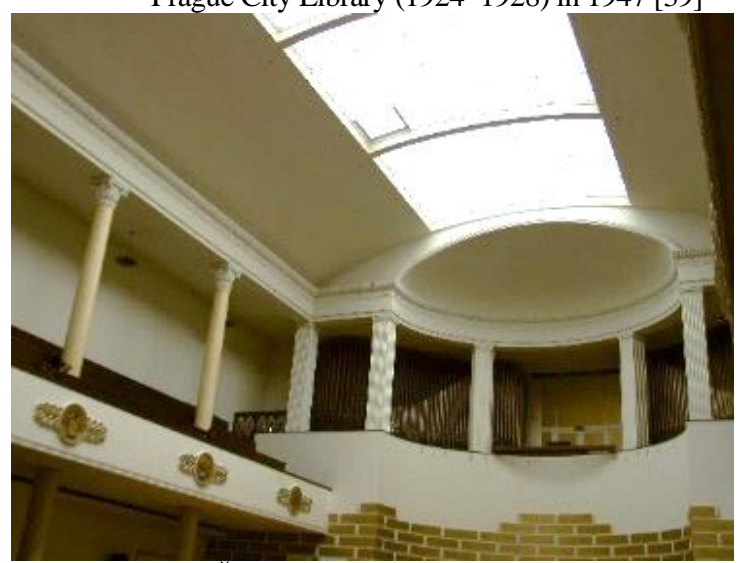

Fig. 4. Ernests Šâlbergs, Large Hall of the University of Latvia, 1931-1936 [46]

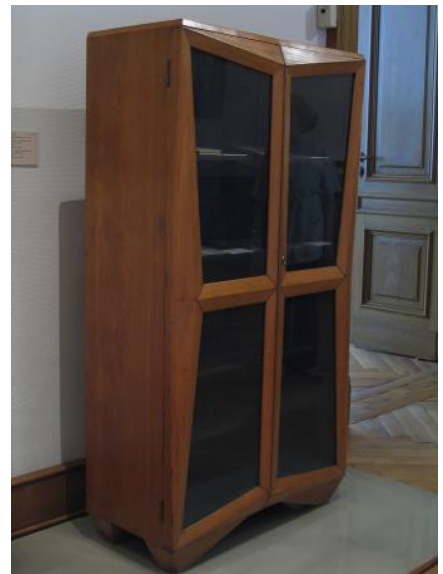

Fig. 6. Pavel Janák, bookcase, Czechoslovakia, 1912-1913 [37]

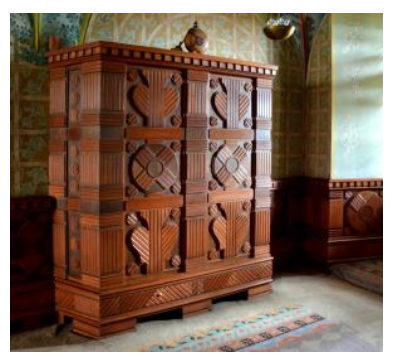

Fig. 9. Pavel Janák, the Star sign (Zverokruh) dining room, 1924, at the Renaissance and

Baroque Bartoň-Dobenín family palace (1501-1660) [38]

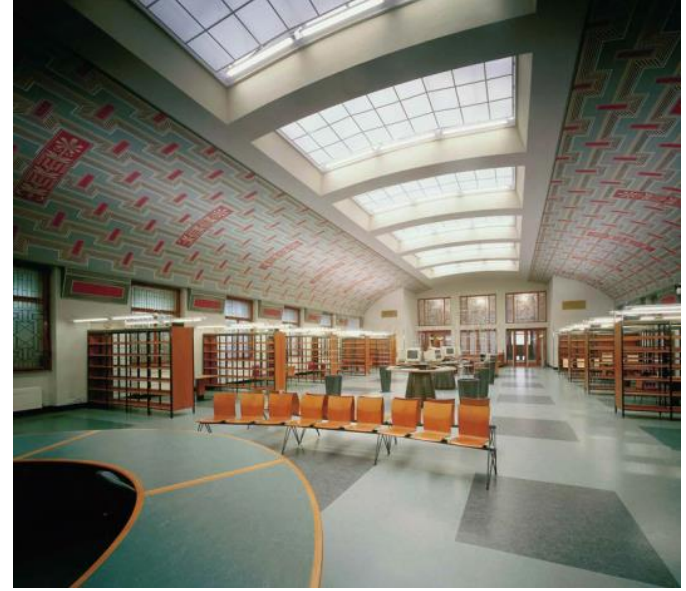

Fig. 3. František Roith, Prague City Library (1924-1928) hall after reconstruction in 1998 [33]

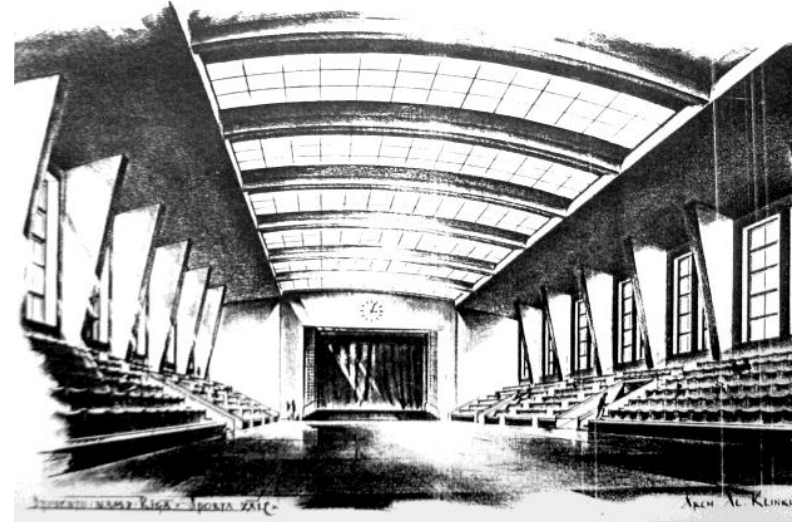

Fig. 5. Aleksandrs Klinklāvs, project proposal for the universal hall of the Riga Students' Building, 1933 [42]

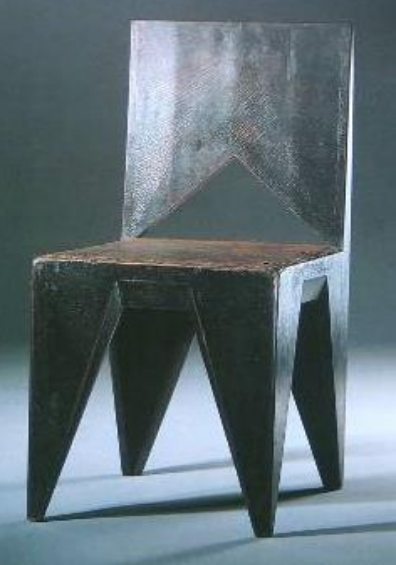

Fig. 7. Vlastislav Hofman, chair, Czechoslovakia,

1912-1913 [35]

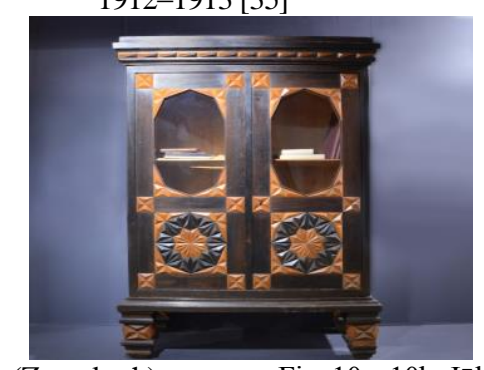

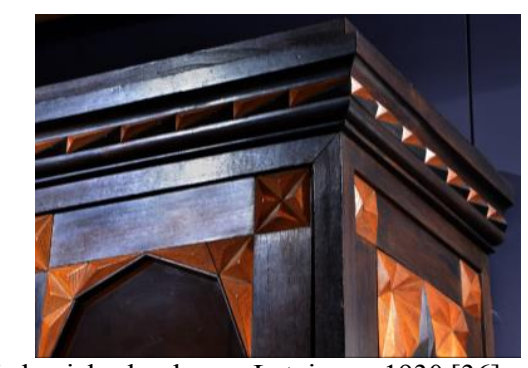

Fig. 10a, 10b. Jūlijs Madernieks, bookcase, Latvia, ca. 1930 [36]

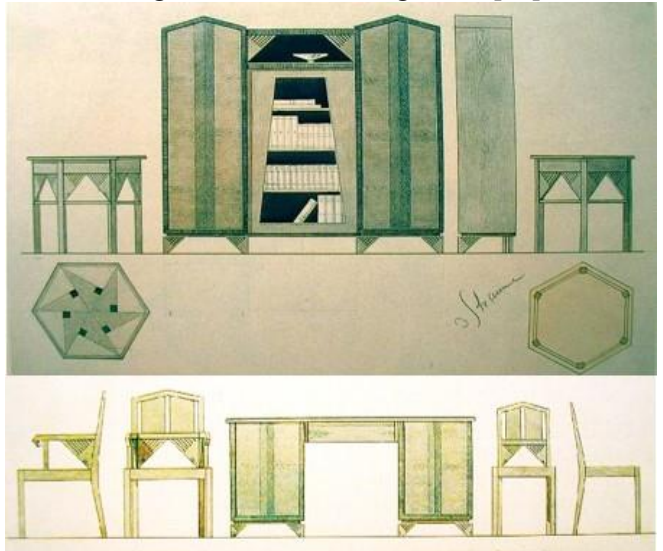

Fig. 8a, 8b. Jūlijs Straume, Latvia, ca. 1936 [40] 

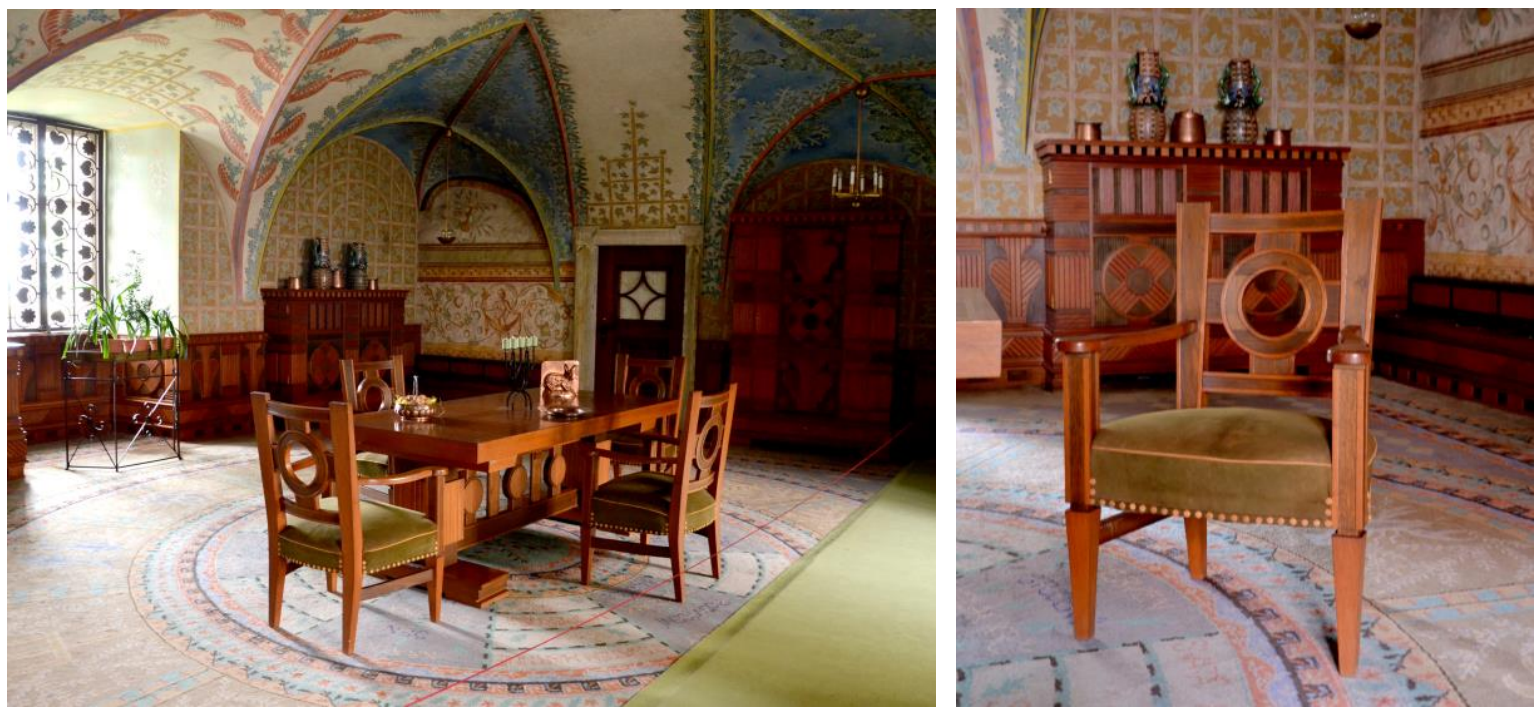

Fig. 11a, 11b. Pavel Janák, The Star sign (Zverokruh) dining room, 1924, at the Renaissance and Baroque Bartoň-Dobenín family palace (1501-1660), Nové Město nad Metují, Chech Republik [38]
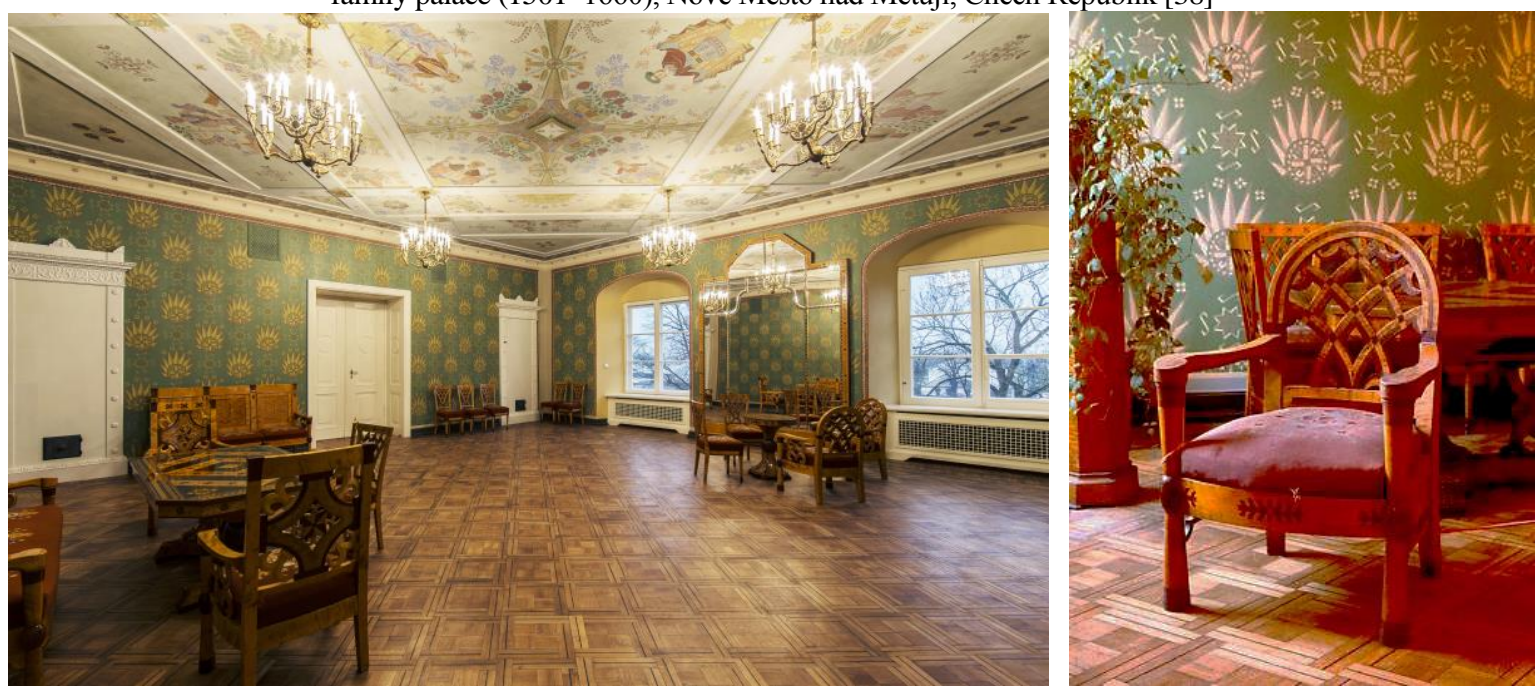

Fig. 12a, 12b. Ansis Cïrulis, The Ambassador Accreditation Hall, 1926-1929, at Riga Castle (1330-1515), Riga, Latvia [43]

building of the Riga Latvian Theatre would only later disappear from buildings designed by Roith, with the arrival of stronger modernist accents.

The trend among architects to transition from historicalized architecture to a geometrialization of forms can be clearly seen in Latvian architecture; however, only in the Czech Republic this trend blossomed into architectural Czech Cubism. In Western Europe, the transition to the geometric form and linear rhythm in architecture was initiated by Auguste Perret, Otto Wagner and Josef Hoffmann, the latter of which designed furniture with proportion-wise elaborate shapes made of straight lines as early as in 1900 , in a similar way to that of Scottish architect Charles Rennie Mackintosh. The trend among architects to simplify forms to basic geometrical forms is reflected in applied arts; analogies can be seen in Jūlijs Straume's furniture design (around 1936) (Fig. 6a, 6b) and in Vilis Vasarinšs's pottery which are similar to the works of Czech cubists in terms of massing.
The striking example of references to the crystallization forms of architectural Czech Cubism is the book cabinet made by Jūlijs Madernieks (Fig. 7a, 7b), which simultaneously displays the contemporary aesthetics of Art Deco. The examples merely confirm the views held by Sigfried Giedion that cubism was a manifestation of the quest that many artists were on, rather than an invention of any single person, for example, Picasso [5].

\section{Interpretation of Folklore and Art Deco}

Regardless of creative potential, artists and architects in many of the new states conformed with the flow of contemporary trends, including folklore, which became one of the defining sources of inspiration for stylization. The self-determination of the new states, which used to be and still is typical of all cultures and civilisations, manifested itself by means of expression found in folklore.

The boom in decorativeness in architecture in the 1920s and 30s is associated most closely with Art 
Deco aesthetics, in which stylizations of folkloristic ornaments and forms occupied a niche among the many variants. Although according to a number of researchers [1] Art Deco complies with difficulty to attempts at defining it precisely, one of these variants deserves the name Folkloristic Art Deco. These processes share an analogous interpretation of folklore characterizing the era, and, in accordance with stylization of forms, can be included into the niche of folkloristic Art Deco. In some examples, a conscious pronouncedly modernized and exaggerated/exacerbated deviation from the authentic ethnographic model can be seen, thus highlighting a post-modernistic trend.

During the interwar period, phenomena in which inspiration or quotes from folklore can be found to a lesser or greater degree had names related to "adjacent" cultural phenomena: in Latvia, contemporaries used the term Nationally Constructive style, because Russian constructivism was topical; the term National Romanticism, Folk Romanticism or Latvian style has also been retained. The latter designation applies to the time before the First World War; however, as the term and phenomenon Art Deco in art and architecture was defined as late as in the 1960s, a certain patriotic continuity of the concept determines that in Latvia, phenomena including elements of folklore are attributed to national Romanticism. In Poland, it is called the Zakopane style (styl zakopiański), because it drew inspiration from the culture of the mountain-dwellers of Zakopane; in Czechoslovakia, it is known as Rondocubism (rondokubismus), because architectural Czech Cubism had just ceased to exist as a phenomenon prominent and pronounced only in Czech architecture. Discussion regarding the time period in Czech architecture from 1920 to 1923 is relevant; the period is defined as the last phase of architectural Czech Cubism - the third cubism style, and as the Legiobank style (sloh Legiobanky) [8], the national style (národní sloh, národní styl) and national decorativism (národní dekorativismus) $[13,14]$. Historian Zdeněk Lukeš characterizes work from this period as a specific Czech version of Art Deco [24]. Also, when writing about the success of Czech applied arts at the 1925 exhibition in Paris, Milena Lamarova remarks that manifestations of national decorativism, or Czech Art Deco, in applied arts has come to an end [13].

In Polish art history, the term Polish Art Deco "national-folkloristic style" (ludowo-folklorystyczny) can be found in characterizations of the art and architecture included within the scope of Art Deco aesthetics [27]. Scientist Irena Humla proposes the term "the style of regained independence" (,styl odzyskanej niepodległości”) [11], whereas when the creative work of Polish artist Zofia
Stryjeńska from 1891 to 1976 is discussed, it is consistently attributed to folkloristic Art Deco [34].

National folklore as a significant artistic presentation for architecture has been used in Latvia, Czechoslovakia and Poland. For example, the representative portrait of Polish president Prof. Dr. Ignacy Mościcki with kilim with folklore motifs in Art Deco style on the background; the Star sign (Zverokruh) dining room, so-called President's Hall in the Bartoň-Dobenín family palac (1501-1660; Nové Město nad Metují), that was reconstructed by Frantiśek Kysela and Pavel Janák in 1921-1924 (Fig. 8a, 8b).

A similar reconstruction was also carried out in Latvia, the most ornate manifestations of folkloristic Art Deco attributed to Ansis Cīrulis, who implemented the theme of Art Deco mirth and the sun in the interior of the Ambassadors' Accreditation Hall in Riga Castle (the castle of the Latvian president since 1918) in the time period from 1926 to 1929: the saturated green hue used on the walls with an unusual symbolism of the sun, rhythmically arranged murals symbolizing the optimism of the nation, as well as such custom-made interior items as rugs, curtains, ceiling lamps and furniture decorated with intarsia (Fig. 9a, 9b).
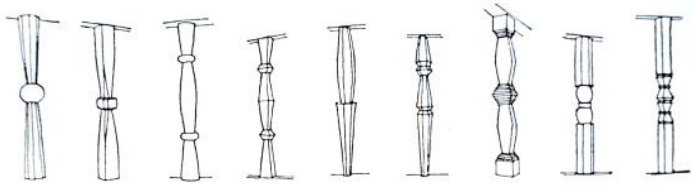

Fig. 13. Examples of posts in Latvian vernacular architecture acording to Pauls Kundziņš's 1952 publication Zwei bezeichnende Schmuckformen in der frühen Holzarchitektur Nordeuropas [41]

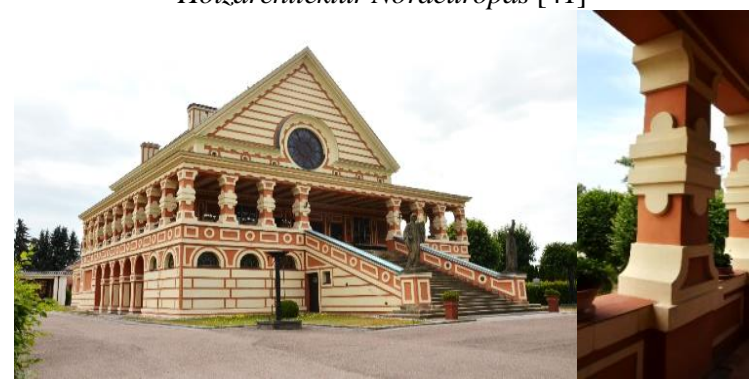

Fig. 14a, 14b. Pavel Janák. The crematorium in Pardubice, Czech Republic, 1922-1923 [46]

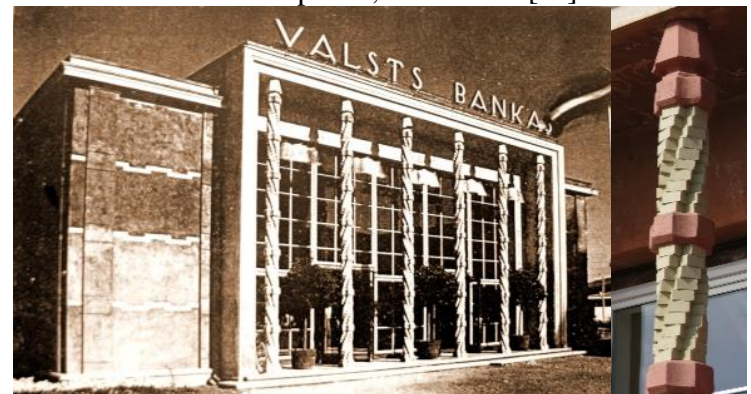

Fig. 15a, 15b. Pauls Kundziņš, The pavilion of the National Bank at the exhibition of Zemgale Region in Jelgava, Latvia, 1937 [50; 46] 


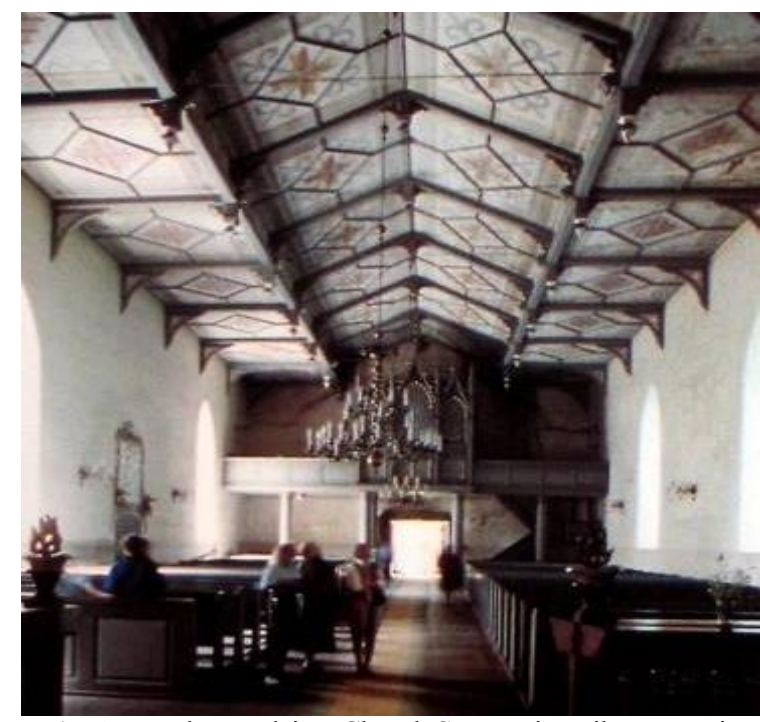

Fig. 16. Pauls Kundziňš. Church St. Jāna in Trikāta, Latvia $(1607 ; 1694)$ interior with ceiling painting in 1930s. [49]

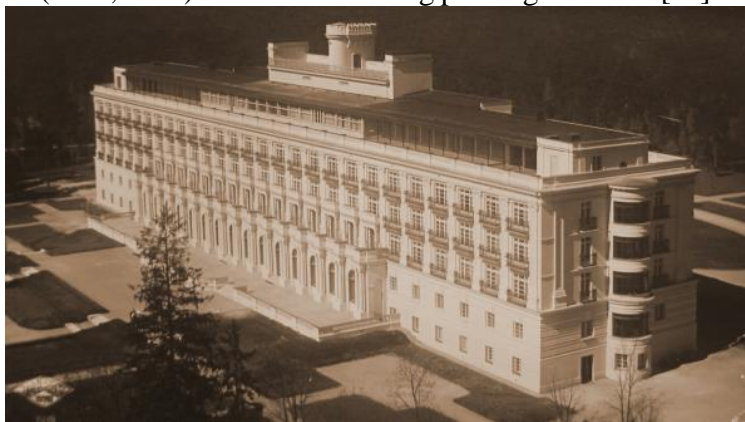

Fig. 18. Eižens Laube, Resort hotel «Ķemeru viesnīca», Jūrmala, Latvia, 1933 [47]

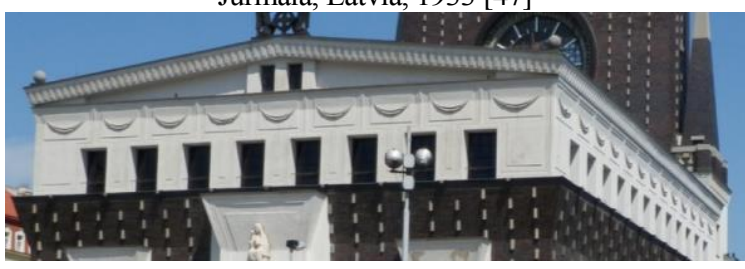

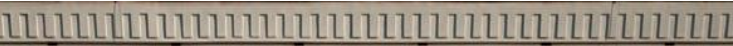

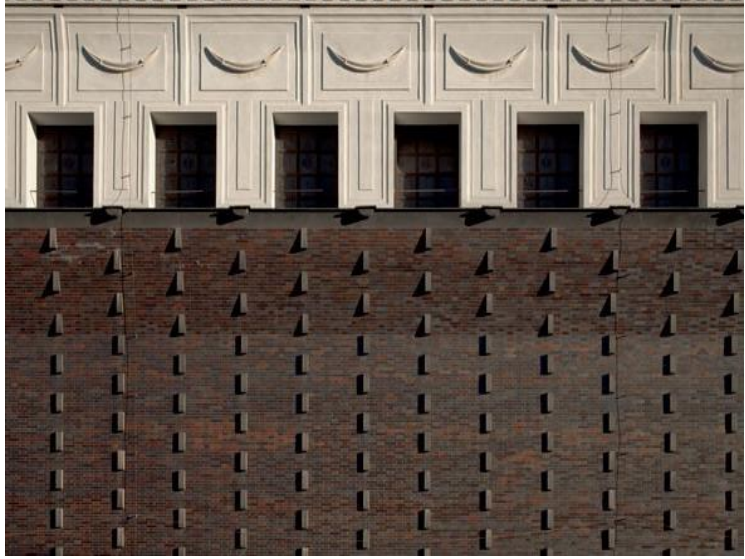

Fig. 20a, 20b. Jože Plečnik, Church of the Most Sacred Heart of Our Lord in Prague, Praha. 1928-1938 [46].

Facade building ornaments inspired in Classicism.

Our Lady, modernism in the tectonics of the façade and classical ornaments - co-existence of various eras

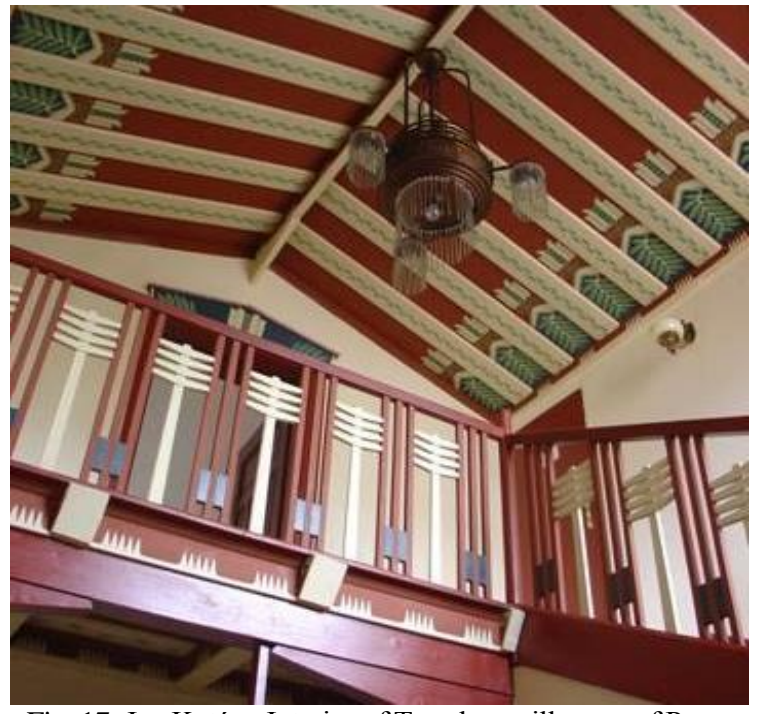

Fig. 17. Jan Kotéra. Interior of Trmalova villa near of Praga (Praha-Strašnice), Czech Republic. 1902-1903 [51]

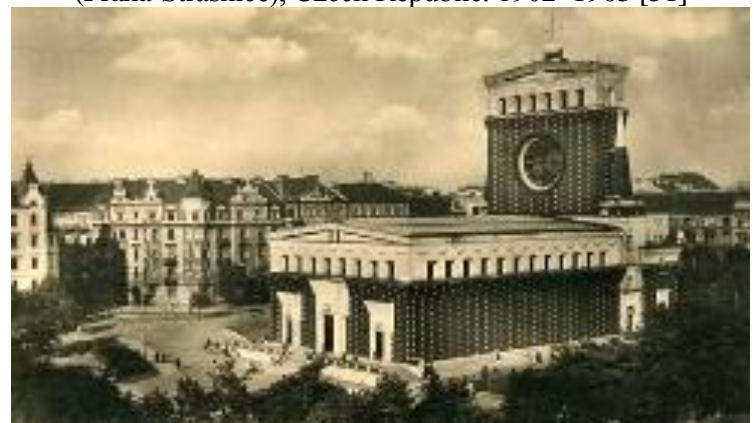

Fig. 19. Jože Plečnik, Church of the Most Sacred Heart of Our Lord in Prague, 1928-1938 [44]

A peculiarity of the Czech people - the idea to announce their national self-determination and protest against the Catholic church by means of crematorium architecture - manifested itself in a pronouncedly folkloristic manner in Pavel Janák's design in Parubice (1921-1923). Rich in murals by František Kysel [25], the crematorium has been made similar to vernacular architecture and at the same time continues the rhythm of forms borrowed from Renaissance that were a favourite with Czech cubists. In Latvia, however, the shape of vernacular posts (examples of posts in Latvian vernacular architecture according to Pauls Kundziņšs's 1952 publication Zwei bezeichnende Schmuckformen in der frühen Holzarchitektur Nordeuropas) (Fig. 10), which in Janák's work are stylised in a 'cubist' manner, was expressively rendered in brickwork by Pauls Kundziņš (1937, the stanchion at the entrance to the National Pavilion of Banks at the exhibition in Jelgava), thus affirming the close ties between the folklore of various European nations (Fig. 12a, 12b).

Both prior to the First World War and during the interwar period, the style of interiors inspired by a feeling of national patriotism included the principles of folkloristic Art Deco. The geometricalized polychrome interior of the villa of Jan Kotera Trmalov (1902-1903) near Prague (Praha-Strašnice), the Zakopane style room at Dr. Dlusk's sanatorium in Zakopane, (1910; 
author of the interior - Wojciech Brzega), the ceiling of Trikāta Church designed by Pauls Kundziňš (Fig. 13), with stylized vernacular ornaments, and the interior designed by Slovenian architect Dušan Jurkovič for a hotel in Pustevny (1897-1899, Radhošt, the Czech Republic) are all like this.

\section{Modernization of Classical Forms}

Both Jānis Čakste and Tomáš Garrigue Masaryk, the respective presidents of Latvia and the Czech Republic, saw architecture as a major tool for representing the new state and manifesting the independence and mightiness of the new state. The 1920s were dominated by folkloristic Art Deco, whereas the 30s saw an arrival of stylized classical forms. The president's castle, which is building number one for every country, was to become a herald of the mightiness of statehood, which can be most directly achieved by using the forms of classical antiquity. Latvian Eižens Laube and Slovenian Jože Plečnik were contemporaries of the same age and were prominent representatives of their profession, and a number of important parallels can be identified in the professional activities of the two architects at this time.

Laube and Plečnik masterfully used the means of expression of the architectural traditions of classical antiquity, and the use thereof in the creative work of Laube and Plečnik shows the two architects' attitude to the universalism of these forms within a context of modernism. Both architects recognized the language of classical architecture as a basis for the development of architecture, at the same time synthesizing it with modern means of expression rather than blindly following it. Both architects worked on the modernization of the stately residence of the president. In the $1930 \mathrm{~s}$, both architects developed solutions that were unusual and nontraditional for their country for large-scale construction projects representing the new statehood: Laube's design for the Kemeri Hotel (1933), and Plečnik's design for the Church of the Most Sacred Heart of Our Lord in Prague (1928-1938, Kostel Nejsvětějšího Srdce Páně) (Fig. 18a, 18b, 21). Both masters of architecture can be considered early postmodernists [16].

In 1920, Slovenian architect Jože Plečnik, who was one of the most talented students of Otto Wagner, officially appointed by president Tomáš Garrigue Masaryk, became architect for Prague Castle in Hradčany, the residence of the president of Czechoslovakia. Due to his major contribution to Czech architecture, he is often also called a Czech architect [9], because his creative
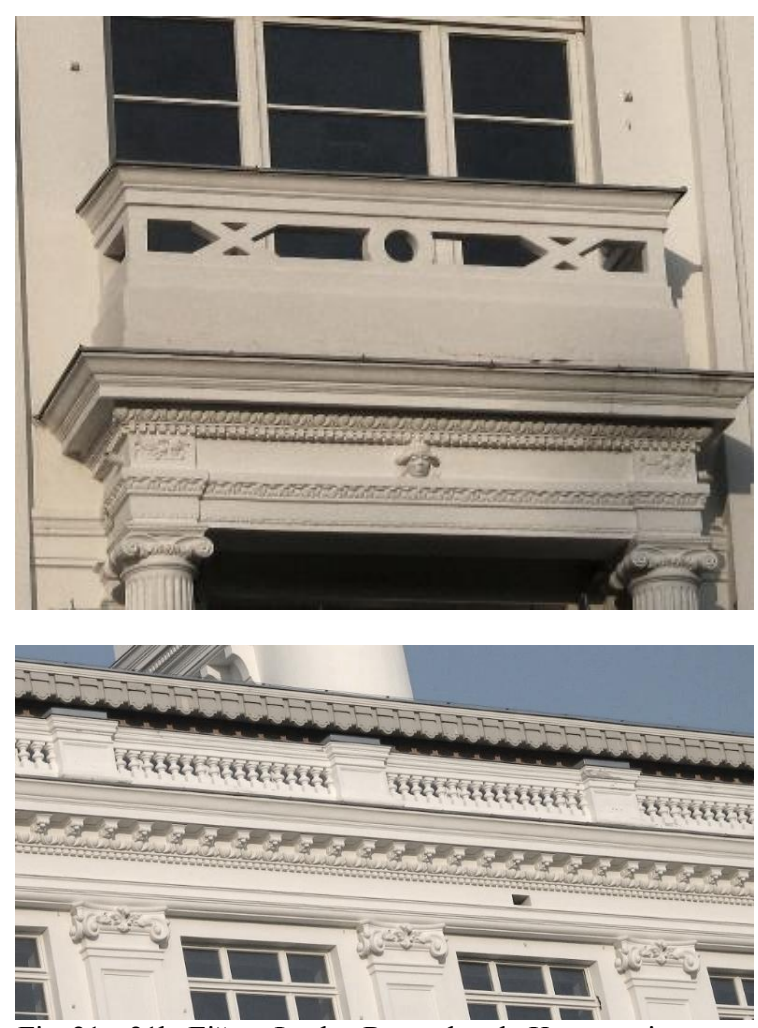

Fig. 21a, 21b. Eižens Laube, Resort hotel «Kemeru viesnīca», Jūrmala, Latvia, 1933 [46]. Facade building ornaments rooted in Classicism. The head of a young girl in folk costume with crown, modernism in the balcony railing and classical ornaments - co-existence of various eras

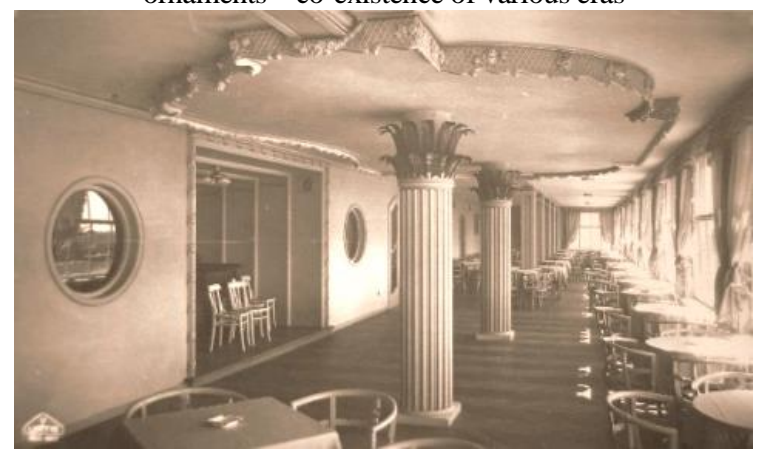

Fig. 22. Roof café, Resort hotel «Kemeru viesnīca», Jūrmala, Latvia, 1933 [48]

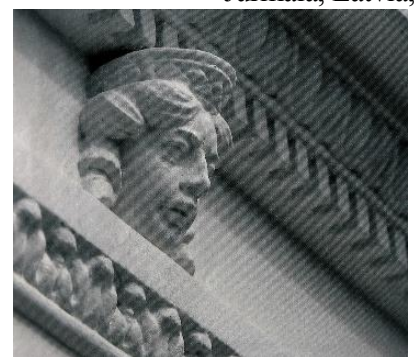

Fig. 23. Young girl with wreath or crown in fasade. Eižens

Laube, Resort hotel

«Ķemeru viesnīca», Jūrmala, Latvia, 1933 [45]

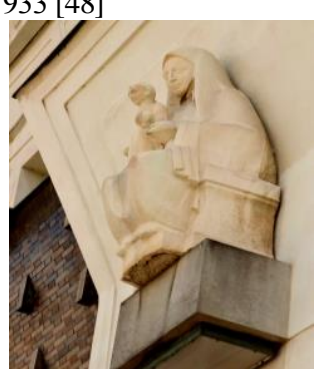

Fig. 24. Our Lady with Christchild - central front entrance sculpture Jože Plečnik, Church of the Most Sacred Heart of Our Lord in Prague, 1928-1938 [46] 
work belonged to three cultures, namely, Slovenian, Czech, and Austrian, which for a long time were united in a single state. Plečnik was fascinated by Venetian architecture, especially Palladianism, until in the $30 \mathrm{~s}$ he gave in to the fashions of Neoclassicism. Moreover, he was fascinated by a legend that Slovenians were the descendants of Etruscans, which contributed to him involving the architecture of classical antiquity even more [29]. However, with his unique rather 'Egyptian-esque' laconism, which was heralded in a most ornate way in the centre of Prague, in Vinohradi, Plečnik's 20th century Classicism differed significantly from universally accepted concepts. From 1928 to 1938, a rather bold idea synthesizing inspiration drawn from Art Nouveau and Classicism was implemented, resulting in a wonderful design: The Church of the Most Sacred Heart of Our Lord in Prague (Kostel Nejsvětějšího Srdce Páně) rises mightily skyward like an ancient Mesopotamian temple. Historian Cezary Wąs interprets it as a large tombstone, a monumental memento mori, whose belfry with its oversized clock draws attention to the transitory nature of earthly life [28, 64].

The massing of the Church of the Most Sacred Heart of Our Lord is avant-garde and the colour contrasts between the various hues - a bright white hue on the upper floors and entrance portals as opposed to the pronouncedly dark semi-basement floor, as well as contrasts between planes, with their rich texture resembling ermine - create a symbolic allusion to Biblical texts to do with the spiritual ruler (king) (this is an almost postmodern interplay of ornamental clinker brickwork) on the semi-basement floor contrasting with the comparatively serene wall planes on the upper floors. This might be one of the interpretations of Plečnik's famous work. According to the writings of English architecture historian Richard Weston, the Church of the Most Sacred Heart of Our Lord, like many of Plečnik's projects, was designed drawing inspiration both from semantic and tectonic motifs [31] (Fig. 18a, 18b).

Eižens Laube is one of the most prominent Latvian architects, and his creative work started in the Art Nouveau era - at a time when the eclectic style was coming to an end and new architectural principles were taking shape. His contribution to the visual image of Riga is significant, with over 100 residential and public buildings constructed. The 'brightest testimony' [15] of Laube's professional career - the Kemeri Hotel (1933), which has been recognised as neo-eclecticism structure and listed among the three most prominent monuments of the monumentalism era of the 1930s in Latvia, brings to mind England in the 1930s, when SS Normandie, on its maiden voyage in 1935, was “like a floating advert for L'Art Décoratif" [26].
Art Deco, which had been called 'the liner style' since the first trans-Atlantic voyages of British shipping company Royal Mail Steamer in 1907 when the large ocean liners RMS Mauretania and RMS Lusitania began a new leisure era in shipping, conquered the seas. It shaped the legendary image of elite life and transformed ships into floating palaces and flats into ship cabins. It cannot be denied that the design of the modern ships influenced the architectural forms of the time [10].

Although the new Latvian state did not have a Normandie of its own, the lavish design of Laube's Kemeri Hotel, nicknamed 'the White Palace', embodied the legend of sophisticated aristocratic life that stemmed from les Années folles and that was transferred to large ships in the 1930s. In the architectural forms of the hotel, Eižens Laube masterfully embodied the metaphor of the mighty ocean liner, at the same time implementing the representative function for the Latvian state in the structure. The aesthetic principle of the metaphor, which was popular in structures built in the Art Deco style of the 1930's (the wheel motif in the Chrysler building in New York is a typical example; 1928-1930, architect William van Alen), blends organically into the scenery of Kemeri Park, the evergreen splendour of which highlights the monumentality of the 'white ocean liner'. The hotel could create a festive ambiance, and prior to the first World War, it was popular with both Latvian citizens and prominent people from all over Europe, such as former monarchs including the Albanian royal couple, as well as London bankers, which the press did not hesitate to show in photo coverages $[2 ; 18]$.

At a time when fascination with the fluid lines of Streamline Moderne ran wild in building designs as a reaction against the language of the rectangular forms of functionalism [20], Laube chose to implement a unique take on the 'ship' trend of the 1930 s in Kemeri woods, using the language of neoeclecticism. The design of the hotel comprises elements of classicism, Baroque, functionalism, as well as Latvian folklore, the latter co-exist harmoniously in the solutions used for the exterior and the interiors: here, the image of a young woman in Latvian folk costume co-exists with structural ornaments rooted in Classicism on the façade (Fig. 19); an oriental or French motif enriched with Art Deco aesthetics appears in the interiors; with a change in point of view, the building looks as compelling as a mighty Baroque palace if looked at from the side of the park, whereas on the main façade, a captain`s bridge beckons as if from a medieval ship. The eclectic accents have been masterfully amalgamated into a single harmonious whole, but in general they speak the language of Art Deco principles. 
Metaphor has been used in the visual image of the monumental massing: an interpretation of the liner and polychrome motifs of classical antiquity, a similar rhythm in the arrangement of the façade details, and idealization of a sculptural image of a woman. This, as well as the premises of the hotel that, according to Agatha Christie, were "cleverly decorated by a modern form to resemble a ship's cabin de luxe" [3], can be seen in the preserved photographs of the roof café, with porthole windows on one side and a glass wall on the other, creating the illusion of a ship deck. The solution used for the capitel of the columns in the café hall shows signs that respect was paid to the allure of pharao-ruled Egypt, which had fascinated Europeans since the Napoleonic era and saw an extremely expressive stylization in hotels and restaurants within the framework of Art Deco. (Fig. 20) Chair back spindles with a dynamically winding cut accentuate the forms of 1930s Art Deco.

The creative manifestation of both these works was defined by two key aspects: modernization of classical forms, and a desire to represent the self-determination of one's nation by means of architecture and to demonstrate the national architecture. Both female images by architects E.Laube and J.Plečnik represent Latvian and
Chech women from the common folk (Fig. 21). Jože Plečnik`s and Eižens Laube`s masterpieces in Prague and Jūrmala, respectively, share monumentality and mightiness at the same time maintaining an analogous considerativeness for the national heritage of one`s country.

\section{Conclusions}

Drawing parallels and searching for analogies and similarities, it can be concluded that the vernacular ornaments and the stylization of the motifs in Latvian and Czech folkloristic Art Deco are contextually and stylistically similar and that there is a willingness to bring poetic folklore characters to life in architecture. In representative architecture, when searching for means of national self-expression, the vernacular, the modern and the classical are synthesized, which in the 1920s can be associated with folkloristic Art Deco, whereas in the 30s, modernized classicism can be identified. As the art history of any nation includes the communicative aspect, it would be impossible to interpret its materials in isolation from other schools, even if they form transcultural rather than direct connections.

\section{References}

1. Bédoyére C. de la, Art Déco. London: Flame Tree Publishing, 2005, p. 384.

2. Bērni jūras svētkos. Atpūta, 1939, Vol. 768, p. 13.

3. Christie, A., Three act tragedy. London: Harper Collins, 2006, p. 15.

4. Giedion S. Space, Time and Architecture: The Growth of a New Tradition. Cambridge, Mass: Harvard University Press, 2002, p. VI.

5. ibidem, p. 31 .

6. Hanson, J. Stockholm - meeting point and source of inspiration. Architecture 1900: Stockholm, Helsinki, Tallinn, Riga, St. Petersburg. J. Howard (ed.), Kirjastus Eesti Tallinn: Arhitektuurimuuseum, 2003, p. 127.

7. Herscher, A. Monument stylu a historická monumentalita. Architekt, 1998, No. 19, p. 48.

8. Hnídková, V. Rondokubismus versus národní styl. Umění / Art, 2009, Vol. 57, Issue 1, p. 74-84.

9. Horešovská, M. Plečnik v Praze tvořil málo, nechtěl brát práci českým kolegům, 2007. [online 3.03.2017] http://www.archiweb.cz/news.php?action=show\&type=1\&id=2668

10. Howard, J., Szczerski, A. Ships in the Night along the Coasts of Bohemia? Modern Design Aesthetics and the Turn of the Liner. In: Modern Art and Central Europe 1918-1968. Vojtěch Lahoda (ed.). Praha: Ústav Dějin Umění AV ČR, 2006, pp. 111-123.

11. Huml, I. Polska sztuka stosowana. Warszawa: Wydawnictwa Artystyczne i Filmowe, 1978, pp. 9-64.

12. Krišane, I. Neīstenotais Aleksandrs Klinklāvs. Mākslas vēsture un teorija, 2006, Vol. 1, pp. 5-14.

13. Lamarová, M. Od rondokubismu k Art Deco. Nový IN, 1998, Vol. 4, pp. 16-19.

14. Legiobanka. Fričová, Y. (ed.). Praha: Titanik, 2015, p. 72.

15. Lejnieks, J. 20. gadsimta pasaule Latvijā. Vai to vainot? Latvijas Arhitektūra, 1999, Vol. 26 (2): pp. 12-20.

16. Lejnieks, J. Laube un Plečniks. Konǵenialitāte. Latvijas Architektūra, 2003, Vol. 6 (50), p. 62.

17. Lejnieks, J. Rīga, kuras nav = Never-built Riga = Ein Riga, das es nie gegeben hat. Rīga: Zinātne, 1998, p. 397.

18. Lejnieks, J., Kemeru viesnīca. Māksla, 1996, No. 3, pp. 37-42.

19. Olszewski A.K., Art Deco. Towards the Definition and Chronology of the Style. Polish Art Studies, Vol. XIV, 1992, p. 73.

20. Olszewski, A.K., Amerykański streamline a europejski modernizm. In: Modernizm w Europie, modernizm w Gdyni. Architektura lat międzywojennych i jej ochrona. M. J. Sołtysik, R. Hirsch (eds.), Gdynia: Urząd Miasta Gdyni, 2009, pp. 31-36.

21. Petrová, S. K art deco přes postmodernu. A naopak? Umění a řemesla, 1989, Vol. 2, pp. 8-10.

22. S. J. [Silinš J.] Arhitektūras izstāde. Izglīitības Ministrijas Mēnešraksts, 1935, Vol. 1, pp. 82-83.

23. Spārītis, O. Nīderlande, Polija un Livonija - kultūrās izstarojuma un uztveres problēmas aspekti. Latvijas Zinātņu Akadēmijas Vēstis, 2004, Vol. 58(4), pp. 40.-62.

24. Stavební uméní. Kubistická architektura v Praze a jejím okolí. Kolber, G. (ed.), Christoph Hölz, Ch. München: Bayerische Vereinsbank 1994, p. 72. 
25. Švácha R. Lomené, hranaté a obloukové tvary: česká kubistická architektura 1911-1923. Praha: Gallery, 2000, pp. 184-186, 215.

26. Tołloczko Z., T. W kręgu architektury Art Déco. Wydawnictwo Oddziału PAN, Kraków, 1997, p. 43.

27. Tolloczko, Z. Jeszcze o „stylu zakopiańskim” i jego wpływie na architekturę modernistyczną. Przyczynek do kwestii zaniku ludowej inspiracji w architekturze końca XX wieku. Czasopismo Techniczne, Politechnika Krakowska, Z. 1A, 2000, p. 16-25.

28. Wąs, C. Antynomie współczesnej architektury sakralnej. Muzeum Architektury we Wrocławiu, Wrocław, 2008, p. 322.

29. Wąs, C. Architektura Jože Plečnika. Muzeum Architektury we Wrocławiu, Wrocław, 2004, 63 p.

30. Weber, E. American Art Deco. North Dighton: World Publications Group, 2004, p. 112.

31. Weston, R. Materials, Form and Architecture. Laurence King, London, 2003, p. 183.

32. Wettbewerb für ein Drittes (Lettisches) Stadttheater in Riga. Architektenverein, Jahrbuch für bildende Kunst in den Ostseeprovinzen, Herausgeber: Der Architektenverein zu Riga., 1911, V. Jahrgang, pp. 88-89. [online 5.03.2017.] http://archiv.riga-digitalis.eu/jahrbuecher/Jahrb_bild_Kunst_Ostseeprovinzen/Hd_39_1911/\#89/z

33. Zavadil J., Grosz J. Rekonstrukce městské knichovni v Praze. Architekt, 1998, No. 19, pp. 42-47.

34. Luba I. Dialog nowoczesności z tradycją. Malarstwo polskie dwudziestolecia międzywojennego. Warszawa: Neriton, Instytut Historii Sztuki Uniwersytetu Warszawskiego, 2004, pp. 120-128.

Photographic sources:

35. Český kubismus: architektura a design 1910-1925. A. von Vegesack (ed.). Weil am Rhein: Vitra Design Museum, 1991, p. 212

36. From the collection of the Museum of Decorative Arts and Design in Rīga, photo by Renāte Čaupale, 2016.

37. From the exposition of the National Technical Museum in Prague, photo by Renāte Caupale, 2006.

38. From the exposition of the Renaissance and Baroque Bartoň-Dobenín family palace (1501-1660), Nové Město nad Metují, Chech Republik, photo by Renāte Čaupale, 2016.

39. Hanzlíková, L. Ústřední knihovna MKP oslavila osmdesátku, 2008 [online 1.03.2017] https://ikaros.cz/ustredniknihovna-mkp-oslavila-osmdesatku

40. Kḷaviņa, L. Jülijs Straume. Lietišķās mākslas meistars. Rīga: Zinātne, 2004, p. 159.

41. Kundziņš, P. Tautas celtniecības rotājumu motīvi jaunceltnēs. Latvijas Architektūra, 1938, No. 1, p. 19.

42. Latvian Museum of Architecture, F. K1 (Aleksandrs Klinklāvs).

43. Ne acu nenovērst: atjaunots Anša Cìruḷa meistardarbs Sūtṇu zālē. [online 7.09.2016] http://www.la.lv/ne-acunenoverst-atjaunots-ansa-cirula-meistardarbs-sutnu-zale/

44. Nový, O. Česká architektonická avantgarda. Praha: Prostor, 2015, p. 159.

45. Photo by Ilmārs Znotiṇš, SestDiena. No. 175, 2004, 30.jūl./6.aug., p. 10.

46. Photo by Renāte Čaupale, 2006, 2009, 2016

47. Resort hotel "Ķemeru viesnīca", Jūrmala, Latvia, postcard, publisher "Fotobrom”, ca.1930, RVKM (Museum of the History of Riga and Navigation), Inv. No. 135593.

48. Roof café, Resort hotel "Kemeru viesnīca", Jūrmala, Latvia, photo by V. Upītis, 1930s, RVKM (Museum of the History of Riga and Navigation), Inv. No. 150147.

49. Spārītis, O. Latvijas luterānnu dievnamu šodiena. Rīga: Nordik, 1999, p. 73.

50. Tīlmanis, O. Dr. arch. P. Kundziņa darbs mūsu tautas celtniecības pieminekḷu kopšanā. Latvijas Architektūra, 1938, No. 6, p. 214.

51. Trmalova vila [online 6.04.2017] http://www.prague.eu/en/object/places/389/trmal-villa-trmalova-vila

INFORMATION ABOUT THE AUTHOR:

Renāte Čaupale - Ph.D. in Architectural History (2010, RTU). Docent at the study programme Architecture of Riga Technical University (RTU), researcher in Latvia University of Agriculture (LLU), Department of Landscape Architecture and Planning. Academic and research interests: history of 20th \& 21st century architecture, Art Deco. E-mail: Renate.Chaupale@gmail.com

Kopsavilkums. Mākslas un arhitektūras saskarsmju kopsakarības starp Latvijas un Čehijas tautām ir salīdzinoši fragmentāras. Tomēr pastāvot vienā lielā Eiropas kultūrtelpā, atrodamas gan paralēles, gan analogiijas, jo to nosaka mākslas un arhitektūras komunikatīvā loma.

Divdesmitā gadsimta divdesmitajos - trīsdesmitajos gados jaunās valsts Latvijas arhitektūrā bija saskatāmas noteiktas, tam laikam Eiropai raksturīgas, aktivitātes. Art Deco estētika bija viens no nozīmīgākajām arhitektoniskajām un mākslinieciskajām izteiksmēm starpkaru periodā. Tās izteiksme mainījusies līdzi laikam, tomēr saglabājot Art Deco dekorativitātes principus. Art Deco estētika ietver vairākus atšķirīgus, bet savstarpēji saistītas tendences, tostarp:

Folkloras interpretāciju - Ansis Cīrulis Latvijā un Pavel Janák Čehoslovākijā meistarīgi veidoja interjerus atbilstoši modernām stilizācijas tendencēm. Neatkarīgi no viṇu radošā potenciāla, mākslinieki un arhitekti daudzās jaunajās valstīs iẹ̦āvās laikmeta tendenču plūsmā, arī folkloras, kas kḷuva par vienu no noteicošajiem iedvesmas avotiem, stilizācijā. Tā ar folkloras izteiksmi manifestējot jauno valstu pašnoteikšanos, kas bija tipiski visām kultūrām un civilizācijām. Šos procesus vieno analoǵiska folkloras interpretācija, kas pieḷauj ietvert tos folkloristikā Art Deco nišā. Atsevišķos piemēros, kad folkloristiskais Art Deco reprezentējas kā 1920.-1930. gadu modernisma mākslas un arhitektūras organiska sastāvdaḷa, 
saskatāma apzināta, izteikti modernizēta atkāpe no autentiskā etnogrāfiskā parauga, tā iezīmējot prepostmodernisku ievirzi.

Klasisko formu modernizāciju, kas bija aktuāla tieši vadonības kulta periodā pirms Otrā pasaules kara. Vēlme ar arhitektūru reprezentēt savas tautas pašnoteikšanos un izteiktie laikmeta nosacījumi noteica Jože Plečnika un Eižena Laubes meistardarbu Prāgā un Jūrmalā monumentalitāti, vienlaicīgi saglabājot analogu iejūtību pret nacionālo mantojumu, ar to būdami tik atšķirīgi.

Latvijā un Čehoslovākijā ir likumsakarīgi atrodams Eiropas zemēm identisks kultūras substrāts, nevis nejaušu gadījuma rakstura ieskaloti stilu mākslas elementi. Jebkuras tautas mākslas vēsture ietver sakaru aspektu, jo nav iespējams tās materiālu interpretēt izolēti no citām skolām, pat, ja tās neveido tiešus sakarus, bet transkulturālus, un darbā ar piemēriem tiek atklāts Latvijas un Čehijas nacionālās arhitektūras idejiskās kopsakarības. 